\title{
Spatiotemporal patterns in seedling emergence and early growth of two oak species direct-seeded on abandoned pastureland
}

\author{
Etienne LALIBERTÉ ${ }^{1,2 *}$, Alain COGLIASTRO ${ }^{1}$, André BouCHARD $^{1}$ \\ ${ }^{1}$ Institut de recherche en biologie végétale (IRBV), Université de Montréal, 4101 Sherbrooke Est, Montréal, QC, Canada H1X 2B2 \\ ${ }^{2}$ Current address: School of Forestry, University of Canterbury, Private Bag 4800, Christchurch 8140, New Zealand
}

(Received 13 November 2007; accepted 31 January 2008)

\begin{abstract}
-
- Fine-scale spatial and temporal establishment patterns of direct-seeded oaks on abandoned agricultural land have been little studied despite their potential importance for long-term stand structure.

- Here we periodically monitored seedling emergence and early growth of bur oak (Quercus macrocarpa Michx.) and red oak (Q. rubra L.) on an abandoned pasture, and tested the effects of herbaceous competition, rodents, and soil physicochemical properties.

- Herbaceous competition slightly decreased diameter growth, but rodents had little impact on establishment. Red oak seedlings emerged earlier than bur oak and in a greater proportion (92\% vs. 56\%). Seedling emergence and early growth of both species showed significant spatial structures that were partly explained by variation in soil physicochemical properties. Bur oak was more responsive to microenvironmental heterogeneity than red oak, yet much of the variation in emergence and growth of both species remained unexplained.

- This suggests that other factors, such as acorn size or genetic variability, may exert equal or greater control than microenvironmental heterogeneity over seedling emergence and early growth of these two oak species on abandoned pastureland.
\end{abstract}

afforestation / Quercus macrocarpa / Quercus rubra / direct seeding / old-field

\begin{abstract}
Résumé - Patrons spatio-temporels d'émergence et de croissance initiale des semis de deux espèces de chênes semées dans un pâturage abandonné.

- Les patrons spatiaux et temporels à échelle fine de l'établissement de chênes semés en friche agricole ont été peu étudiés bien que ceux-ci puissent avoir des impacts à long terme sur la structure du peuplement.

- Nous avons périodiquement suivi l'émergence et la croissance initiale de semis de chêne à gros fruits (Quercus macrocarpa Michx.) et de chêne rouge ( $Q$. rubra L.) dans un pâturage abandonné et évalué l'effet de la compétition herbacée, des rongeurs et des propriétés physico-chimiques du sol.

- La compétition herbacée a légèrement réduit la croissance en diamètre, mais les rongeurs ont eu peu d'impacts sur l'établissement. Les semis de chênes rouges ont émergé plus rapidement que ceux du chêne à gros fruits et dans une plus grande proportion (92\% vs. 56 \%). L'émergence et la croissance en hauteur des deux espèces exhibaient des structures spatiales significatives qui étaient partiellement expliquées par la variation des propriétés physico-chimiques du sol. Le chêne à gros fruits était plus influencé par l'hétérogénéité microenvironnementale que le chêne rouge, bien que la plus grande partie de la variation de l'émergence et de la croissance des deux espèces soit restée inexpliquée.

- Cela suggère que d'autres facteurs, tels que la grosseur des glands ou leur variabilité génétique, pourraient exercer un contrôle aussi ou plus important que l'hétérogénéité microenvironnementale sur l'émergence et la croissance initiale de ces deux espèces semées dans des pâturages abandonnés.
\end{abstract}

afforestation / Quercus macrocarpa / Quercus rubra / semis direct / friche

\section{INTRODUCTION}

During the last two decades there has been a trend in eastern North America towards abandonment of marginal agricultural land (Lepers et al., 2005; Millenium Ecosystem Assessment, 2005). Tree composition of reinvading forests is frequently dominated by pioneer wind-dispersed tree species and natural regeneration of late-successional species is often insufficient (D'Orangeville et al., in press), primarily because tree recruitment in agricultural landscapes is constrained by limited seed dispersal from neighboring forest fragments (McEuen and Curran, 2004). Such dispersal limitation is especially important for large-seeded species such as oaks (Quer-

* Corresponding author: etiennelaliberte@gmail.com cus sp.) whose seeds fall within short distance from parent trees (Clark et al., 1998; García and Houle, 2005). Consequently, artificial regeneration of oak species is generally recommended to ensure their presence on abandoned agricultural land (Allen et al., 2001). While oak afforestation operations have traditionally relied on nursery-produced seedlings (e.g. Cogliastro et al., 1997; Truax et al., 2000), direct oak seeding is another interesting option that has been used in southern Scandinavia (Madsen and Löf, 2005) and in bottomland hardwood restoration in the southeastern United States (King and Keeland, 1999).

Several factors can greatly influence the early establishment success of direct-seeded oaks on abandoned agricultural land. For example, rodents can cause heavy losses due to acorn 
(Madsen and Löf, 2005) and seedling predation (Manson et al., 2001; Ostfeld et al., 1997). Also, early oak establishment can also be compromised by herbaceous competition (Allen, 1990; Löf et al., 2004; Löf and Welander, 2004), yet the strength of this effect appears to be strongly linked to soil water availability. Indeed, herbaceous competition has strong negative impacts on early oak growth in mediterranean regions where water deficits during the growing season are important (Esteso-Martinez et al., 2006; Rey Benayas et al., 2003; Rey Benayas et al., 2005), but can have no influence in more mesic conditions (Wittwer, 1991).

In addition to rodent herbivory and herbaceous competition, fine-scale microenvironmental heterogeneity can also potentially influence the establishment of direct-seeded oaks on abandoned agricultural land. While the effects of a heterogeneous environment on oak recruitment, particularly heterogeneity in light resources, have been relatively well studied in forests (Ashton and Larson, 1996; Battaglia et al., 2000; Collins and Battaglia, 2002; García and Houle, 2005; McCarthy and Evans, 2000) and woodlands (Puerta-Piñero et al., 2007), the effects of microenvironmental heterogeneity has been comparatively little studied in more open habitats such as recently abandoned agricultural land (but see Harrison and Werner, 1984). High resource heterogeneity is frequently observed in recently abandoned fields (Kelly and Canham, 1992), and can, in turn, greatly influence tree seedling growth (Laliberté et al., in press). In particular, there is increasing recognition that soil heterogeneity has important consequences for individual plants, plant populations and plant communities (Hutchings et al., 2003). However, to our knowledge no study has yet examined how the fine-scale spatial patterns of emergence and early growth of direct-seeded oaks within a single field are influenced by variation in soil physicochemical properties. Moreover, while several studies have analyzed the inter-annual temporal patterns of oak seedling establishment in various regions and environments, the fine-scale temporal patterns of oak establishment have rarely been studied within the first growing season (but see Danner and Knapp, 2001).

Because long-term success or failure of oak direct seeding is largely dependent on first-year establishment (Madsen and Löf, 2005), and because the early stages of recruitment in most plant populations are particularly vulnerable to biotic and abiotic stressors (Harper, 1977), the fine-scale spatial and temporal establishment patterns of direct-seeded oaks may have significant long-term impacts on stand structure. Consequently, the objective of the present study was to analyze in detail, both in space and time, the seedling emergence and early growth patterns of bur oak (Quercus macrocarpa Michx.) and red oak (Q. rubra L.) that were direct-seeded on an abandoned pasture and to test the effects of competing vegetation, rodent herbivory, and underlying soil physicochemical properties.

\section{MATERIALS AND METHODS}

\subsection{Study area and site description}

A site located in the Upper-Saint-Lawrence region of southwestern Québec (Canada) was selected for this study $\left(45^{\circ} 08^{\prime} \mathrm{N}\right.$;
Table I. Soil physicochemical properties of the study site.

\begin{tabular}{lcc}
\hline & Mean & $(\mathrm{SD})$ \\
\hline $\mathrm{pH}$ & 7.4 & - \\
{$[\mathrm{H}+](\mathrm{mol} / \mathrm{L})$} & $4.01 \times 10^{-8}$ & $\left(1.45 \times 10^{-8}\right)$ \\
$\mathrm{CEC}(\mathrm{meq} / 100 \mathrm{~g})$ & 19.9 & $(2.9)$ \\
$\mathrm{P}(\mathrm{kg} / \mathrm{ha})$ & 12.2 & $(9.9)$ \\
$\mathrm{K}(\mathrm{kg} / \mathrm{ha})$ & 177.8 & $(50.2)$ \\
$\mathrm{Mg}(\mathrm{kg} / \mathrm{ha})$ & 1535 & $(209)$ \\
$\mathrm{Ca}(\mathrm{kg} / \mathrm{ha})$ & 6270 & $(966)$ \\
$\mathrm{Al}(\mathrm{ppm})$ & 598.6 & $(80.9)$ \\
Organic matter $(\%$ weight $)$ & 7.7 & $(2.2)$ \\
Sand $(\%$ weight $)$ & 44.2 & $(6.6)$ \\
Silt $(\%$ weight $)$ & 43.1 & $(5.2)$ \\
Clay $(\%$ weight $)$ & 12.7 & $(2.2)$ \\
Soil stoniness $(\%$ vol.) & 35.0 & $(23.5)$ \\
Soil water $(\%$ vol.) & 18.3 & $(2.6)$ \\
Depth H horizon (cm) & 5.0 & $(1.1)$ \\
Depth A horizon (cm) & 14.6 & $(2.7)$ \\
\hline
\end{tabular}

Means and standard deviations (SD) are calculated from fifteen soil samples spread across the study site (one per experimental block).

$\left.74^{\circ} 22^{\prime} \mathrm{W}\right)$. The region, one of the most productive agricultural areas of Québec, is characterized by a humid continental climate with mean annual temperatures of $6^{\circ} \mathrm{C}$ and monthly means of $21{ }^{\circ} \mathrm{C}$ and $-10{ }^{\circ} \mathrm{C}$ for July (warmest month) and January (coldest month), respectively (Meteorological Service of Canada, 2006). Mean annual total precipitation is $1030 \mathrm{~mm}, 18 \%$ of which is snowfall.

The surficial deposits of the Upper-Saint-Lawrence are mainly of marine, glacial, late-glacial or littoral origin (Bariteau, 1988). These deposits overlay Beekmantown dolomite to the west and Postdam sandstone to the east (Globensky, 1987). The region was colonized in the early 19th century, and intensive forest exploitation by settlers has had a great impact on current forest composition (Bouchard and Domon, 1997; Brisson and Bouchard, 2003). About 29\% of the region is covered by forest today and the remaining territory is mainly occupied by agricultural activities (Soucy-Gonthier et al., 2003).

The study site was a pasture which had been abandoned one year prior to the start of the study. Overall topography was flat, although the northwestern corner of the site was slightly sloping. Prior to the establishment of the experiment, vegetation was primarily composed of herbaceous species such as Phleum pratense L., Poa pratensis L., and Echium vulgare L. Small patches of the shrub Zanthoxylum americanum P. Mill. also occurred but were cut to ground-level prior to acorn sowing. Vegetation composition did not change noticeably for the duration of the experiment (one year).

A few large bur oak and red oak trees were found in the vicinity of the study site, suggesting that edaphic conditions were appropriate for the growth of both oak species. No trees were growing directly in the area where the experiment was established, and the closest mature trees were located far enough away $(\sim 30 \mathrm{~m})$ as to have no edge effects on the light regime in portions of the experiment. Soils were composed of a sandy loam interspersed with outcropping Beekmantown dolomite. A summary of soil physicochemical properties of the study site is given in Table I. 
Table II. Description of the development stages used for both oak species.

\begin{tabular}{ll}
\hline Development stage & Description \\
\hline 0 & No signs of germination visible from aboveground. \\
1 & First few days of germination; shoot is bent, its tip still belowground. \\
2 & Shoot is entirely aboveground, but bent. No leaves. \\
3 & Shoot is straight. First set of leaves $(2)$ is visible, but small $(<1 \mathrm{~cm})$. \\
4 & Second set of leaves begins. \\
5 & Third set of leaves begins. \\
6 & Fourth set of leaves begins; lowest leaves still are not mature. \\
7 & Lowest leaves are thick and mature; highest ones are not. \\
$\mathbf{8}$ & First growth flush ends. All leaves are thick and mature. \\
9 & Second growth flush starts; terminal bud barely opened. \\
10 & First set of leaves from second flush is visible, but small. \\
11 & Second set of leaves from second flush begins. \\
12 & Lowest leaves from second flush are thick and mature; highest ones are not. \\
$\mathbf{1 3}$ & Second growth flush ends. All leaves are thick and mature. \\
\hline
\end{tabular}

The qualitative development stages were developed specifically for the present study. Development stages highlighted in bold characters refer the end of a growth flush.

\subsection{Acorn collection and sowing}

Acorns of two native oak species, bur oak (Quercus macrocarpa Michx.) and red oak (Q. rubra L.), were each collected immediately after seed fall under mature trees in 2005. Bur oak acorns were collected on September 25th in Saint-Anicet (QC, Canada), and red oak acorns were collected on October 20th in Montréal (QC, Canada). Acorns were immersed in water overnight and nonviable floating acorns (less than 3\%) were discarded. Viable bur oak acorns were stored in a refrigerator until planting, whereas red oak acorns were not stored since they were sown the day after collection.

On October 21st 2005, all acorns were sown on the study site. Sowing spots (each corresponding to a $\sim 45-\mathrm{cm}$ line along the row) were positioned along 11 rows, and each row was spaced by $6 \mathrm{~m}$. This $3 \times 6-m$ wide spacing was chosen because it is commonly used in hardwood afforestation operations in our region. Within a row, neighboring sowing spots were spaced by $3 \mathrm{~m}$ and there were 13 sowing spots per row. For each row, species were assigned randomly to each of three groups of contiguous sowing spots (i.e. two groups of four contiguous spots and one group of five contiguous spots). Each red oak sowing spot was sown with six acorns, while bur oak sowing spots were sown with only three because of limited acorn supply for this species. In each sowing spot, the stubble was first uplifted with a planting shovel to facilitate sowing and acorns were then hand sown at 5-cm depth (Tomlinson et al., 1997). For both species, about $10 \mathrm{~cm}$ was left between neighboring acorns in each sowing spot. There were 66 red oak and 77 bur oak sowing spots in total, for a total of 396 red oak and 231 bur oak acorns.

\subsection{Experimental design and treatments}

The experiment was set up as a complete randomized block design with three crossed factors: (1) species (bur oak vs. red oak), (2) rodent herbivory (protected vs. unprotected), and (3) competing vegetation (no vegetation vs. intact vegetation). Five contiguous blocks of uneven sample size were used, with each block containing at least one set of all eight possible factor interactions. In the "no vegetation" treatment, herbicide was applied around each sowing spot with a wick applicator three times in 2006 (April 20th, June $21 \mathrm{st}$, and August 9th) in order to obtain a 50-cm radius vegetationfree area around each sowing spot. Herbicide mix was 1:10 Vision ${ }^{\mathrm{TM}}$ (Monsanto Corp., Montréal, QC, Canada; active ingredient, 13.6\% glyphosate). To avoid herbicide contact with oak seedlings, a buffer area (around $15-\mathrm{cm}$ radius or more if needed) around each sowing spot never received herbicide and instead was weeded manually regularly throughout the growing season (April-November 2006). Protection against rodents was done by fencing off individual sowing spots with $30-\mathrm{cm}$ radius, $45-\mathrm{cm}$ high cylindrical enclosures made from 6.4-mm wire mesh, while unprotected sowing spots were left unfenced.

\subsection{Data collection}

All oak seedlings were tagged upon emergence, and their height and development stage (Tab. II) were monitored periodically throughout the 2006 growing season. The qualitative seedling development stages (Tab. II) were specifically developed for the present study. Seedling height and development stage were measured at weekly intervals from May 14th to July 25th, the period of most rapid growth. From July 25 th to November 15th, height and development stage were measured biweekly. During these two periods signs of rodent damage (when present) were also noted. Seedling stem diameter at ground level was measured once, at the end of the growing season (October 16th).

Soil water content (\% vol.) was also measured to a depth of $10 \mathrm{~cm}$ at each sowing spot on August 22nd 2006, using time-domain reflectometry (ML2X probe, $\Delta \mathrm{T}$ Devices, Cambridge, UK). In addition, a hole was dug in the middle of each of the fifteen experimental blocks from which soil percent stoniness, thickness of humic layer, and thickness of the first soil horizon were evaluated. Two soil samples (one for each of the two first soil horizons) were also collected, 
and from these, soil particle size analyses were conducted following the methodology of Boyoucos (1962). Organic matter content (\%) of horizon A was estimated with the loss-on-ignition method. Although this method can overestimate organic matter content in calcareous soils because of the presence of $\mathrm{CaCO}_{3}$ (Soil and Plant Analysis Council, 1992), we were interested in relative values between plots, and not absolute values. The following soil chemistry variables were also measured from theses fifteen soil samples from the first soil horizon: $\mathrm{pH}$ (water and buffer), cation exchange capacity (CEC), as well as $\mathrm{Al}, \mathrm{Ca}, \mathrm{Mg}, \mathrm{K}$, and $\mathrm{P}$ content (Agridirect Inc., accredited laboratory, Longueuil, QC, Canada). We interpolated the soil data gathered from each experimental block to all 143 sowing spots, using the SIGIS software (SIGISCO Inc., Montréal, QC, Canada).

\subsection{Statistical analyses}

A mixed ANOVA model (with blocks as random effects) was used to test for the effects of oak species, herbaceous control, and rodent protection on the timing of seedling emergence (i.e. date of the first seedling emergence for each sowing spot), percent seedling emergence (i.e. number of emerged seedlings relative to the number of acorns sown per spot), as well as height and diameter growth. Individual sets of analyses were conducted from the data of each of the first fourteen censuses (May 16th to September 5th) for percent seedling emergence and height. Seedlings were not thinned to a single seedling per sowing spot, but seedling density (i.e. the number of emerged seedling per sowing spot) had no significant effects ( $p \geq 0.12$; results not shown) on either height or diameter growth of the first-emerged seedlings, and growth analyses (i.e. eight or diameter) were limited only to these first-emerged seedlings. Only surviving seedlings were considered in these analyses. A mixed ANOVA model was also used to test for the effect of surrounding vegetation on soil water content. Where required, rank transformations were used to meet assumptions of normality and homoscedasticity of residuals.

Spatial analyses of the timing and percent seedling emergence, as well as height and diameter growth, were conducted using principal coordinates of neighbor matrices, also called PCNM (Borcard and Legendre, 2002). Species were analyzed separately in these analyses and only surviving seedlings were considered. Also, in these regression analyses all experimental blocks were grouped together and each sowing spot was treated as an experimental unit, but the treatments (i.e. rodent protection and competing vegetation) were used as covariables to control for their potential effect. Forward selection of PCNM variables was done prior to multiple regressions on timing and percent seedling emergence, seedling height and seedling diameter of both oak species, and fitted values were used to build the spatial models. Multiple regressions of environmental variables (also with forward selection) were also conducted on the seedling emergence (timing and percent), height, and diameter raw data, as well as their associated spatial models (i.e. fitted values of PCNM model). Whereas all measured soil physicochemical variables were used in the regressions involving seedling height and diameter, only the following physical variables were used for both timing and percent emergence: soil water, soil organic matter, soil stoniness, depth of soil horizons $\mathrm{H}$ and $\mathrm{A}$, and percent clay, silt and sand of horizon A. These were selected because they were hypothesized to be the most biologically relevant variables which could influence germination and seedling emergence. Soil $\mathrm{pH}$ was expressed as $\mathrm{H}^{+}$ion concentration in regression analyses.
All ANOVA and multiple regression analyses were conducted using JMP (SAS, 2003), while PCNM analysis was done using the "spacemakeR" package (Dray et al., 2006) in the R-language environment (R Development Core Team, 2006). For all analyses, the statistical significance level was set as $p \leq 0.05$. Unbiased adjusted- $R^{2}$ values $\left(R_{a}^{2}\right)$ were used to compare regression models (Legendre and Legendre, 1998).

\section{RESULTS}

\subsection{Acorn and seedling predation}

No acorn predation was seen throughout the study period in either protected or unprotected sowing spots. Although a few voles were seen on the study site, no digging holes or perturbed soil were observed around sown acorns. This observation is supported by the fact that seedling density (i.e. number of emerged seedling per sowing spot) was not significantly different between protected and unprotected spots ( $p \leq 0.53$ for both species). Mortality of emerged seedlings at the end of the growing season was very low for both bur oak $(2.2 \%)$ and red oak $(2.5 \%)$, and since it occurred only in unprotected sowing spots it was mostly attributed to rodent damage.

\subsection{Seedling emergence}

Surrounding vegetation or rodent herbivory had no significant effects on either the timing or percent emergence of both oak species. At all times during the season red oak had significantly higher percent emergence than bur oak ( $p \leq 0.05)$, with the exception of the first census (May 16th). Seedling emergence was first observed during the May 16th 2006 census, with $0.4 \%$ and $6.8 \%$ of all sown bur oak and red oak acorns (i.e. pooled across all sowing spots) having emerged as seedlings by that date, respectively (Fig. 1A). Red oak emergence was largely constrained to the first month, since more than $75 \%$ of all its seedlings had emerged by June 20th (Fig. 1A; empty circles). On the other hand, bur oak emergence occurred more gradually over the season (Fig. 1A; empty squares). Newly-emerged seedlings of both species were no longer observed after August 22nd. At the end of the growing season, all red oak sowing spots (i.e. 100\%), and $90 \%$ of all bur oak sowing spots, contained at least one seedling (Fig 1A; shaded symbols). However, overall percent seedling emergence at the end of the growing season were much higher for red oak $(92 \%)$ than for bur oak $(56 \%)$ (Fig. 1A; empty symbols).

Spatial patterns of percent seedling emergence (see Appendices 1 and 2 for graphs depicting these spatial patterns, available online only) were all highly significantly inter-correlated through time for both species ( $p \leq 0.001$; results not shown). Exceptions to this were the early emergence patterns of bur oak (May 16th and May 23rd), which were not significantly correlated with the patterns observed later in the season; however very few bur oak seedlings had yet emerged in these first two weeks (Figs. 1B and 2). For both species, the patterns of the timing of emergence were significantly spatially structured 

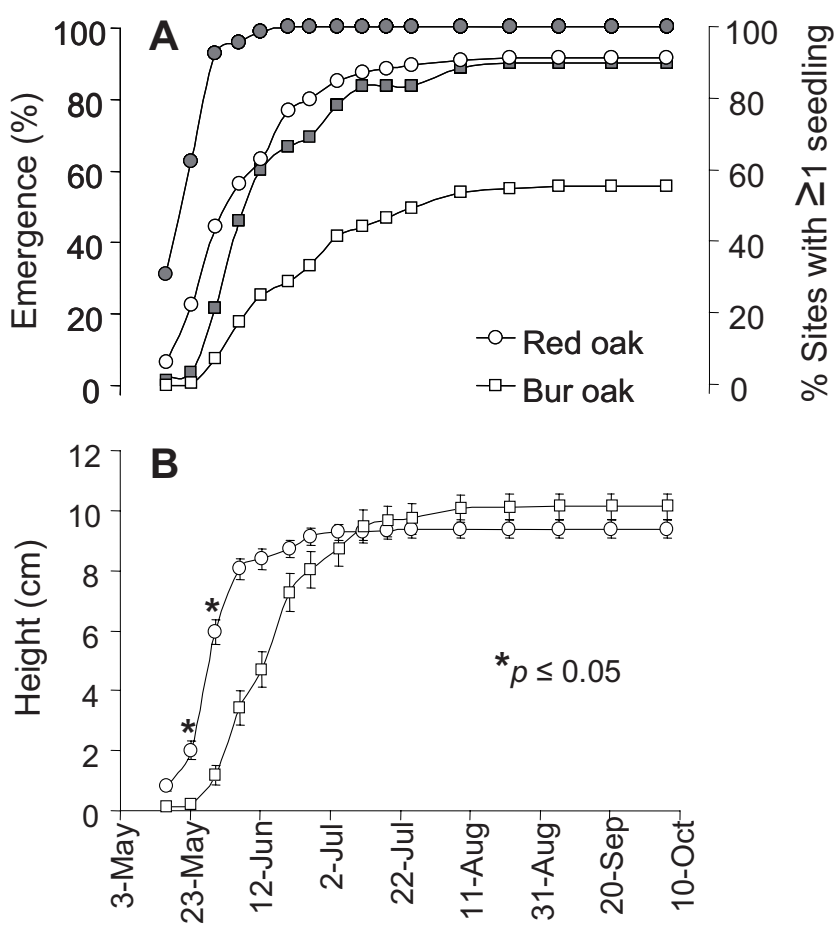

Figure 1. Percent seedling emergence and mean seedling height of both oak species throughout the 2006 growing season. (A) Empty symbols: overall percent emergence (i.e. pooled across all sowing spots), calculated as the ratio between the number of seedlings at stage $\geq 1$ (see Tab. I) and the number of acorns initially planted. Shaded symbols: percent number of sowing spots with at least one seedling. (B) Mean height \pm SE. At each date, pairs of values with an asterisk $(*)$ are significantly different $(p \leq 0.05)$.

( $p \leq 0.01)$, particularly strongly for bur oak $\left(R_{a}^{2}=0.518\right.$; Tab. III) but less so for red oak $\left(R_{a}^{2}=0.183\right.$; Tab. III). For both species, a lower clay or a higher sand content (as well as a lower soil organic matter for red oak) led to earlier seedling emergence (Tab. III). On the other hand, percent seedling emergence patterns of both oak species (i.e. raw data) were not influenced by the environmental variables measured (see Appendix 3 for graphs depicting the spatial variation of the environmental variables, available online only), and even though the patterns of percent emergence exhibited significant spatial structures $(p \leq 0.01)$, these spatial structures were relatively weak $\left(R_{a}^{2}=0.177\right.$, red oak; $R_{a}^{2}=0.203$, bur oak). The spatial structure of red oak percent emergence was not explained by variation of the environmental variables measured, whereas the spatial structure of bur oak emergence was weakly, yet significantly, related to these environmental variables $\left(R_{a}^{2}=0.093, p=0.001\right)$.

\subsection{Seedling development and growth}

Red oak seedlings developed faster than bur oak seedlings, the former reaching development stage 8 (i.e. end of the first growth flush; Tab. II) about one month before the latter (Fig. 2). On the other hand, a larger proportion of bur oak seedlings exhibited a second growth flush (i.e. stage 13; Fig. 2) at the end of the growing season. Red oak seedling height was significantly greater $(p \leq 0.05)$ than bur oak at the beginning of the season, but mean height of both species no longer differed significantly after June 6th (Fig. 1B). Surrounding vegetation or rodent herbivory had no significant effects $(p>0.09)$ on height growth of both species at any time during the 2006 growing season. However, seedling diameter at ground level (which was only measured on October 16th) was slightly, but significantly, greater in vegetation-free spots (3.36 vs. $3.06 \mathrm{~mm} ; p \leq 0.05)$. In vegetation-free spots soil water content was also significantly higher (19.7 vs. $16.8 \%$ vol.; $p \leq 0.01)$.

In addition, bur oak seedling height was weakly, but significantly, influenced by the environmental variables measured $\left(R_{a}^{2}=0.086, p \leq 0.05\right)$, whereas red oak height was not (Tab. III). Seedling height patterns of both species (see Appendices 1 and 2 for graphs depicting these spatial patterns, available online only) showed significant spatial structures $\left(R_{a}^{2}=0.358\right.$, red oak; $R_{a}^{2}=0.481$, bur oak; Tab. III). Multiple regressions of environmental variables on each spatial model showed that these spatial structures were partly deterministic, as they were significantly related to the underlying environment ( $p \leq 0.01$; Tab. III). The environmental variables measured explained $21.8 \%$ of the variation of the spatial structure of bur oak height and $16.1 \%$ of the variation of red oak height (Tab. III). Diameter growth of both species was also significantly spatially structured ( $p \leq 0.01$; Tab. III), but more weakly so than height $\left(R_{a}^{2}=0.177\right.$, red oak; $R_{a}^{2}=0.331$, bur oak; Tab. III). For both species, the environmental variables measured explained little of the spatial structures of diameter growth $\left(R_{a}^{2}=0.090\right.$, red oak; $R_{a}^{2}=0.096$, bur oak; Tab. III), even though these relationships were significant ( $p \leq 0.05$; Tab. III).

\section{DISCUSSION}

\subsection{Acorn and seedling predation}

In the present study rodents had little impact on early oak establishment. No acorn predation was seen, and height growth of both species did not differ between fenced or unfenced plots. The lack of difference in height growth was a direct consequence of the very low rodent damage observed. Such an effect, however, may be detected in the future as the impact of rodents on oak seedling survival and growth is cumulative. With regard to acorn predation, a positive relationship between acorn predation by rodents and amount of overstory cover has been observed in previous studies (Buckley and Sharik, 2002; Gómez, 2004; Johnson, 1983). For example, Buckley and Sharik (2002) reported a five-fold difference in the removal of red oak acorns between clearcut plots versus uncut plots (12\% vs. 59\%, respectively). Gómez (2004) also found that predation of holm oak (Quercus ilex L.) acorns was much lower in open sites relative to closed sites (e.g. under shrubs or trees). 


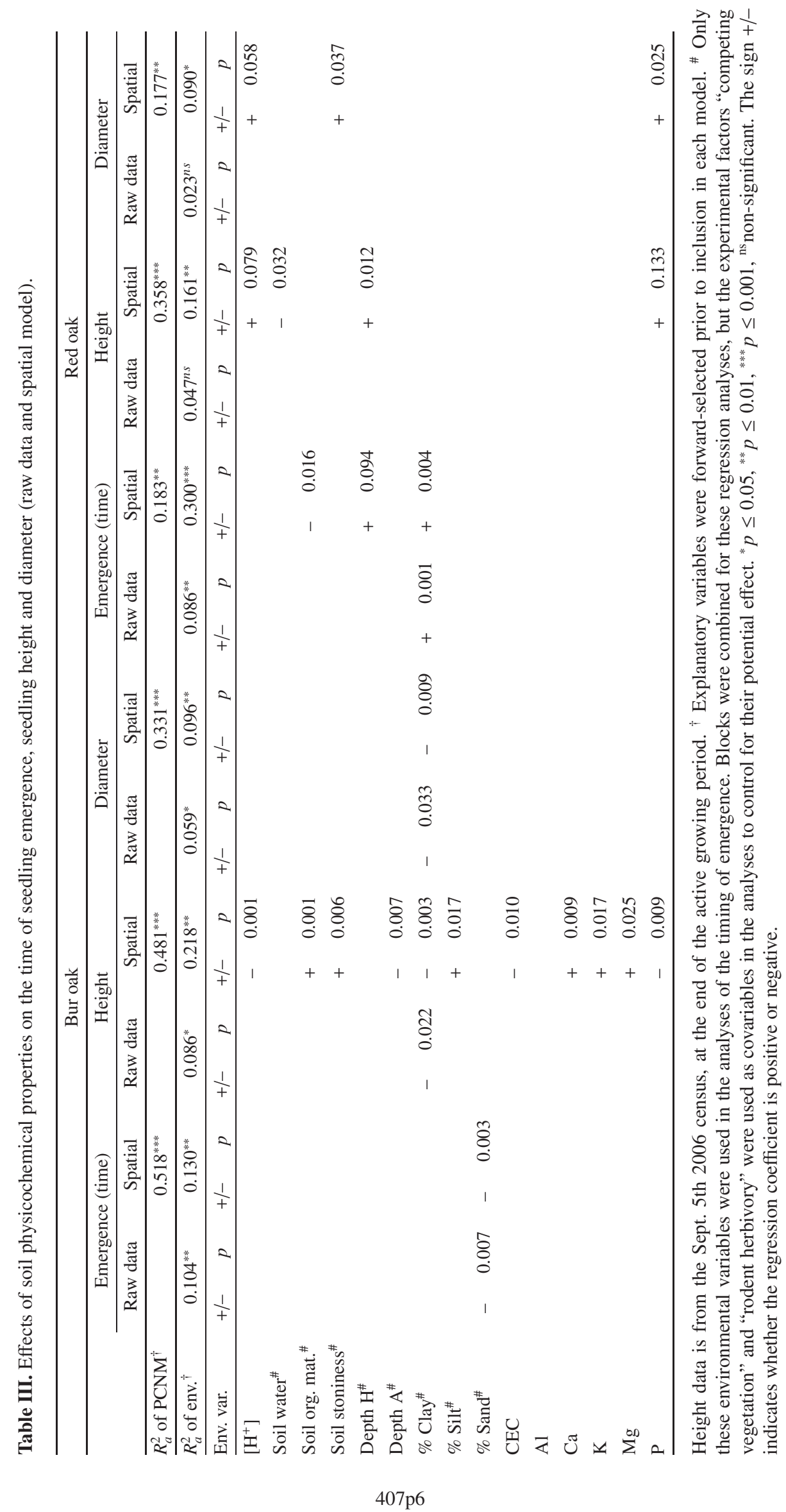




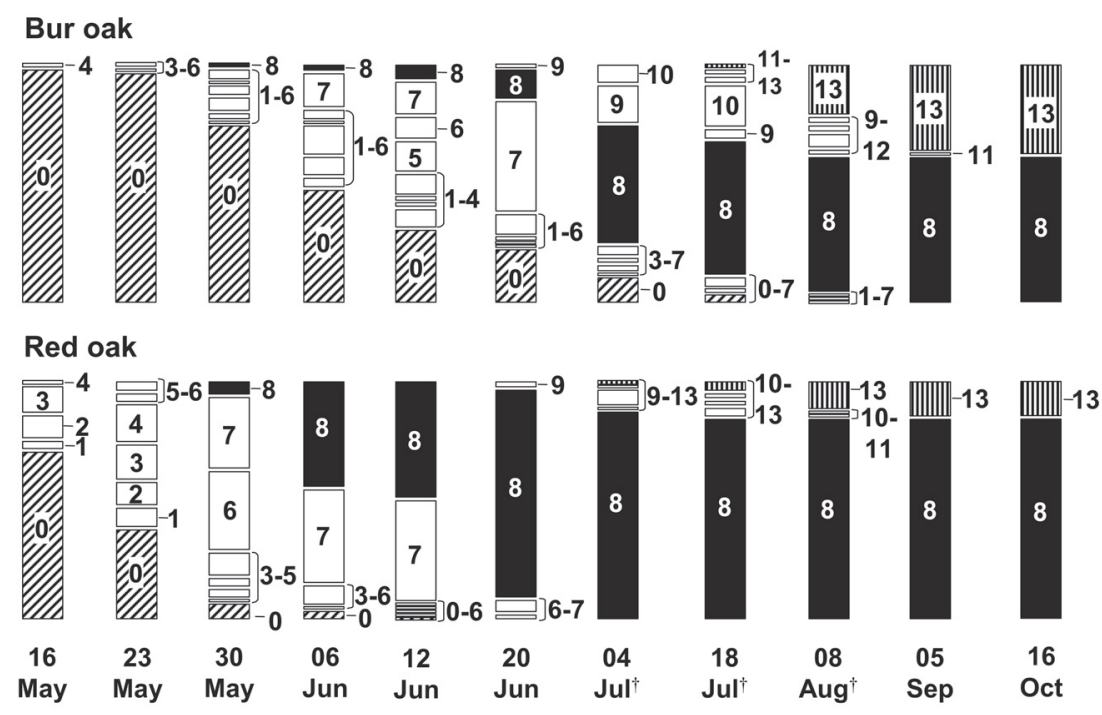

Figure 2. Oak seedling development stage throughout the 2006 growing season. Height of each vertical bar represent the total number of seedlings, and height of each section within a bar indicates the proportion (\%) of total seedlings in that particular development stage. Detailed descriptions of each development stage (0 to 13) are available in Table II. ${ }^{\dagger}$ Some red oak emergence was still observed at these dates, but seedling numbers were so low $(<0.5 \%)$ that they are not shown on the graphs.

A proposed explanation for this general trend is that a high vegetation cover favourably influences rodent foraging patterns since it reduces the risk of being preyed upon (Brown et al., 1988; Lima and Dill, 1990). Given that in the present study vegetation was primarily composed of a rather sparse cover of timothy (Phleum pratense), this may explain why acorn predation was not observed and that seedling predation was very low. However, these results come from one study site only and so should be extrapolated with caution. Because the impact of rodents can greatly vary from site to site due to fluctuating rodent populations (Madsen and Löf, 2005), and because predation appears to be the most frequent cause of failure of oak direct-seeding (Harmer, 1994; Madsen and Löf, 2005; Nilsson et al., 1996), we suggest that a precautionary approach involving some type of protection against rodents should preferably be followed. Still, our results are consistent with the general assumption that lower predation rates occur where vegetation cover is sparse, which is often the case in recently abandoned pastures.

\subsection{Herbaceous competition}

Herbaceous vegetation can reduce oak seedling emergence (Germaine and McPherson, 1999), and sometimes facilitate it (Tonioli et al., 2001), yet in the present study both the timing and percent emergence of both species was not affected by the presence of surrounding vegetation. However, because the stubble was locally uplifted prior to sowing, the likelihood of detecting an effect of vegetation on seedling emergence may have been lessened. In addition, herbaceous vegetation had no effect on height growth of both species, although it slightly decreased diameter growth. This difference was quite small (i.e. $\sim 0.3 \mathrm{~mm}$ ) but nonetheless represented a $\sim 10 \%$ reduction in seedling diameter growth. This shows that herbaceous competition can have measurable impacts on oak seedling diameter growth during the earliest stages of oak establishment on abandoned pastureland, yet it is unclear whether this small and early effect will have long-term biological significance.

Given that soil water content was significantly lower in sowing spots which were surrounded by vegetation, it is likely that competition for soil water was the main mechanism behind this reduction in diameter growth, although competition for light is also possible in herbaceous old-fields (Laliberté et al., in press). Maximum photosynthesis of bur oak seedlings is attained at a photosynthetic photonic flux density (PPFD) of $\sim 400 \mu \mathrm{mol} \mathrm{m}{ }^{-2} \mathrm{~s}^{-1}$ (Hamerlynck and Knapp, 1994) (which corresponds to $\sim 25 \%$ PPFD of the average available PPFD on a sunny summer day in our region), and red oak seedlings show little increases in growth above 15\% PPFD (Kaelke et al., 2001). Therefore, given that the low and sparse herbaceous cover found on the study site blocked very little of the total light available to seedlings (Laliberté, personal observation), we consider it unlikely that competition for light was an important factor in the present study.

Despite the slight reduction in diameter growth, our results did not point out a strong overall impact of herbaceous vegetation on emergence and early growth of direct-seeded oaks on abandoned pastureland. However, it must be stressed again that these results only come from one site and could thus differ depending on context. Because competition for soil water by herbaceous vegetation has often been reported to strongly negatively affect oak seedling growth, especially where water is limiting (Gordon and Rice, 1993; Löf, 2000; Esteso-Martinez et al., 2006), a minimal level of herbaceous control should still preferably be applied following direct seeding of oaks on recently-abandoned pastureland. 


\subsection{Temporal patterns of seedling emergence and growth}

Our results showed distinct temporal patterns of seedling emergence between red oak and bur oak. While red oak seedlings first emerged in mid-May, the first bur oak seedlings lagged behind by almost two weeks. Moreover, red oak emergence was largely constrained to the first three weeks following emergence of the first red oak seedling, whereas bur oak seedlings emerged more gradually throughout the season and newly-emerged ones were still being observed in early August. However, such delayed emergence is not unusual, since an emergence window of a few months has been observed for other species such as holm oak (Gómez, 2004). Although we are unaware of any other study which has observed the delayed emergence of bur oak relative to red oak, this has been observed by forest nursery producers in our region (Anne Déziel, Berthier provincial forest nursery, QC, Canada; personal communication).

In addition to differences in the time of emergence, overall percent emergence at the end of the growing season differed greatly between the two species. While almost all red oak acorns emerged as seedlings (92\%), this proportion was only slightly more than half for bur oak $(56 \%)$. The lower percent emergence of bur oak over red oak could be linked to decreased seed viability due to storage, since bur oak acorns were stored in a refrigerator from September 25th to October 21st while red oak acorns were sown the day after being collected. Moreover, bur oak, like other members of the white oak group, is known to initiate germination in the fall (Johnson, 1990) whereas red oak initiates it in the spring (Sander, 1990), which could have made bur oak acorns more susceptible to winter frost. Still, it is possible that bur oak emergence could be partly delayed to the next season, something which has been observed for other oak species such as Q. ilex (Gómez, 2004) and $Q$. gilva Blume (Tanouchi, 1996).

In addition to emergence, our results also showed that bur oak and red oak exhibited distinct seedling development and height growth patterns. Red oak developed faster and had higher height growth than bur oak earlier in the season, but at the end of the growing season both species were as high and a higher proportion of bur oak seedlings had a second growth flush. Similarly, in another study which compared early development and growth of three oak species, including red oak (i.e. $Q$. rubra, $Q$. coccinea Muenchh., Q. velutina Lam.), it was found that red oak had the greatest height growth after the first growing season but had a lower number of flushes than the other species (Ashton and Larson, 1996). Therefore, it may be that the rapid early height growth and reduced flushing rate of first-year red oak seedlings are characteristics of this species.

\subsection{Spatial patterns of seedling emergence and growth}

While experimental treatments (i.e. rodent protection and herbaceous control) had little or no effect on the early establishment of both oak species, all emergence and growth variables showed significant spatial structures within the study site. The timing of emergence was more strongly spatially structured than overall percent emergence, particularly for bur oak. This suggests that microenvironmental heterogeneity may exert a stronger influence over the speed at which an acorn emerges as a seedling than over the probability of emergence itself, and that bur oak is more sensitive to microhabitat variation than red oak regarding its emergence (both timing and percent).

Percent germination or emergence of various oak species (Q. rubra, Q. velutina, Q. coccinea, Q. ilex, Q. douglasii Hook. \& Arn., Q. pubescens Willd., Q. emoryi Torr.) has often been shown to be significantly affected by environmental heterogeneity (Ashton and Larson, 1996; Broncano et al., 1998; Germaine and McPherson, 1999; Gómez, 2004), but the range of microhabitats compared in these studies was generally much broader (e.g. from open sites to closed-canopy sites) than the one considered here. In the present study, microenvironmental heterogeneity between sowing spots may have been too low to exert strong control over percent seedling emergence. On the other hand, we found that soil texture (and soil organic matter in the case of red oak) influenced the timing of emergence of both oak species. Sowing spots where soils had lower clay or higher sand content (as well as lower organic matter content for red oak) led to earlier emergence. A potential explanation for this is that soils with higher clay or organic matter content generally have greater water-holding capacity, and therefore warm more slowly early in the season. Still, the fact that rarely more than half of the variation of either percent of timing of seedling emergence was spatially structured suggests that other unmeasured factors unrelated to microenvironmental heterogeneity, such as acorn size (Rice et al., 1993; Tonioli et al., 2001; Beon and Bartsch, 2003) or acorn genetic variability (Goodman et al., 2005) may have had an equal or stronger impact on seedling emergence patterns.

In addition to emergence, height and diameter growth patterns of both oak species exhibited significant spatial structures which were partly explained by microenvironmental heterogeneity. The residual spatial variation may have been due to spatially autocorrelated biotic factors such as heterogeneous mycorrhizal infection patterns, which have been reported to affect red oak seedling growth in forest soils (Dickie et al., 2002), but could also be attributed to other unmeasured abiotic variables. As with seedling emergence, height and diameter growth of bur oak exhibited stronger spatial structures than red oak, suggesting that bur oak early growth may be more responsive to fine-scale microhabitat variation than red oak. In addition, the height growth of both species was more spatially structured than their diameter growth, yet the mechanism behind this is unclear.

Although our results showed that height and diameter growth patterns of both species had a significant deterministic (i.e. environmentally-driven) component, much of this variation in growth remained unexplained by either spatial or environmental variables. Similarly to seedling emergence, it is likely that other unmeasured factors unrelated to environmental heterogeneity exerted a strong control over the first-year growth of both oak species. Acorn size, for instance, has been reported to strongly influence first-year growth of various oak 
species in several studies (Bonfil, 1998; Kormanik et al., 1998; Rice et al., 1993).

\section{CONCLUSIONS}

In the present study, rodent herbivory and herbaceous competition had no influence on seedling emergence or height growth of direct-seeded oaks, yet herbaceous competition for soil water slightly reduced diameter growth. However, these results cover only one site and one growing season and so should be extrapolated with caution. On the other hand, the very focus of the present study on small spatial and temporal scales allowed a highly detailed description of the finescale establishment patterns of bur oak and red oak on abandoned pastureland. Red oak seedlings emerged earlier than bur oak, but at the end of the growing season height and diameter growth of both species was comparable. Bur oak was more responsive than red oak to microhabitat variation in both its emergence and early growth. Fine-scale variation of soil texture and soil organic matter influenced the timing of seedling emergence, whereas percent seedling emergence showed weaker responses to microenvironmental heterogeneity. Height and diameter growth of both oak species were partly influenced by fine-scale variation in soil physicochemical properties. Still, it is likely that other factors, such as acorn size or acorn genetic variability, may be at least as important as microenvironmental heterogeneity in driving both the emergence and early growth of these two oak species. Future research should explore in further detail which biotic and abiotic variables best predict the fine-scale spatial patterns of early oak establishment on abandoned agricultural land, and more importantly whether these patterns have long-term consequences on stand structure.

Acknowledgements: We wish to thank D. Hibbs and two anonymous reviewers for helping us to improve the clarity of this manuscript. Thanks to M. Lapointe for help in field work. Research was made possible by a National Science and Engineering Research Council of Canada (NSERC) grant to A. Bouchard and by funding from Institut de Recherche en Biologie Végétale (IRBV) to A. Cogliastro. During the writing of this manuscript, E. Laliberté was supported by doctoral scholarships from University of Canterbury and from the Fonds Québécois de Recherche sur la Nature et les Technologies (FQRNT).

\section{REFERENCES}

Allen J.A., 1990. Establishment of bottomland oak plantations on the Yazoo National Wildlife Refuge Complex. South. J. Appl. For. 14: 206-210.

Allen J.A., Keeland B.D., Stanturf J.A., Clewell A.F., and Kennedy H.E. Jr., 2001. A guide to bottomland hardwood restoration. Res. note SRS-40. USDA Forest Service, Southern Research Station, Asheville, NC, USA.

Ashton M.S. and Larson B.C., 1996. Germination and seedling growth of Quercus (section Erythrobalanus) across openings in a mixeddeciduous forest of southern New England, USA. For. Ecol. Manage. 80: 81-94.
Bariteau L., 1988. La carte géomorphologique au 1:20 000 de modelés polygéniques: un exemple des basses terres du Saint-Laurent. M.Sc. thesis, Département de géographie, Université de Montréal, Montréal, QC, Canada.

Battaglia L.L., Fore S.A., and Sharitz R.R., 2000. Seedling emergence, survival and size in relation to light and water availability in two bottomland hardwood species. J. Ecol. 88: 1041-1050.

Beon M.-S. and Bartsch N., 2003. Early seedling growth of pine (Pinus densiflora) and oaks (Quercus serrata, $Q$. mongolica, $Q$. variabilis) in response to light intensity and soil moisture. Plant Ecol. 167: 97105.

Bonfil C., 1998. The effects of seed size, cotyledon reserves, and herbivory on seedling survival and growth in Quercus rugosa and $Q$. laurina (Fagaceae). Am. J. Bot. 85: 79-87.

Borcard D. and Legendre P., 2002. All-scale spatial analysis of ecological data by means of principal coordinates of neighbour matrices. Ecol. Model. 153: 51-68.

Bouchard A. and Domon G., 1997. The transformations of the natural landscapes of the Haut-Saint-Laurent (Québec) and their implications on future resource management. Landsc. Urb. Plan. 37: 99-107.

Bouyoucos G., 1962. Hydrometer method improved for making particle size analysis of soils. Agron. J. 54: 464-465.

Brisson J. and Bouchard A., 2003. In the past two centuries, human activities have caused major changes in the tree species composition of southern Québec, Canada. Ecoscience 10: 236-246.

Broncano M.J., Riba M., and Retana J., 1998. Seed germination and seedling performance of two Mediterranean tree species, holm oak (Quercus ilex L.) and Aleppo pine (Pinus halepensis Mill.): a multifactor experimental approach. Plant Ecol. 138: 17-26.

Brown J.S., Kotler B.P., Smith R.J., and Wirtz Ii W.O., 1988. The effects of owl predation on the foraging behavior of heteromyid rodents. Oecologia 76: 408-415.

Buckley D.S. and Sharik T.L., 2002. Effect of overstory and understory vegetation treatments on removal of planted northern red oak acorns by rodents. North. J. Appl. For. 19: 88-92.

Clark J.S., Macklin E., Wood L., 1998. Stages and spatial scales of recruitment limitation in southern Appalachian forests. Ecol. Monogr. 68: 213-235.

Cogliastro A., Gagnon D., Bouchard A., 1997. Experimental determination of soil characteristics optimal for the growth of ten hardwoods planted on abandoned farmland. For. Ecol. Manage. 96: 49-63.

Collins B.S. and Battaglia L.L., 2002. Microenvironmental heterogeneity and Quercus michauxii regeneration in experimental gaps. For. Ecol. Manage. 155: 279-290.

D’Orangeville L., Bouchard A., and Cogliastro A., in press. Postagricultural forests: landscape-scale patterns add to stand-scale factors in causing insufficient hardwood regeneration For. Ecol. Manage.

Danner B.T. and Knapp A.K., 2001. Growth dynamics of oak seedlings (Quercus macrocarpa Michx. and Quercus muhlenbergii Engelm.) from gallery forests: implications for forest expansion into grasslands. Trees 15: 271-277.

Dickie I.A., Koide R.T., and Steiner K.C., 2002. Influences of established trees on mycorrhizas, nutrition, and growth of Quercus rubra seedlings. Ecol. Monogr. 72: 505-521.

Dray S., Legendre P., and Peres-Neto P., 2006. Spatial modeling: a comprehensive framework for principal coordinate analysis of neighbor matrices (PCNM). Ecol. Model. 196: 483-493.

Esteso-Martinez J., Camarero J.J., and Gil-Pelegrin E., 2006. Competitive effects of herbs on Quercus faginea seedlings inferred from vulnerability curves and spatial-pattern analyses in a Mediterranean stand (Iberian System, northeast Spain). Ecoscience 13: 378-387.

García D. and Houle G., 2005. Fine-scale spatial patterns of recruitment in red oak (Quercus rubra): What matters most, abiotic or biotic factors? Ecoscience 12: 223-235. 
Germaine H.L. and Mcpherson G.R., 1999. Effects of biotic factors on emergence and survival of Quercus emoryi at lower treeline, Arizona, USA. Ecoscience 6: 92-99.

Globensky Y. 1987. Géologie des basses terres du Saint-Laurent. MM 85-02. Ministère de l'énergie et des ressources du Québec, Québec, Canada.

Gómez J.M., 2004. Importance of microhabitat and acorn burial on Quercus ilex early recruitment: non-additive effects on multiple demographic processes. Plant Ecol. 172: 287-297.

Goodman R.C., Jacobs D.F., and Karrfalt R.P., 2005. Evaluating desiccation sensitivity of Quercus rubra acorns using X-ray image analysis. Can. J. For. Res. 35: 2823-2831.

Gordon D.R. and Rice K.J., 1993. Competitive effects of grassland annuals on soil water and blue oak (Quercus douglasii) seedlings. Ecology 74: $68-82$.

Hamerlynck E., Knapp A.K., 1994. Stomatal responses to variable sunlight in bur oak (Quercus macrocarpa Michx.) leaves with different photosynthetic capacities. Int. J. Plant Sci. 155: 583-587.

Harmer R., 1994. Natural regeneration of broadleaved trees in Britain II: Seed production and predation. Forestry 67: 275-286.

Harper J.L., 1977. Plant Population Biology, Cambridge University Press, Cambridge, UK.

Harrison J. and Werner P.A., 1984. Colonization by oak seedlings into a heterogeneous successional habitat. Can. J. Bot. 62: 559-563.

Hutchings M.J., John E.A., and Wijesinghe D.K., 2003. Toward understanding the consequences of soil heterogeneity for plant populations and communities. Ecology 84: 2322-2334.

Johnson P.S., 1990. Quercus macrocarpa Michx. In: Burns R.M., Honkala B.H. (Eds.), Silvics of North America: Hardwoods. Agriculture Handbook 654, USDA Forest Service, Washington, DC.

Johnson R.L., 1983. Nuttal oak direct seeding still successful after 11 years. USDA Forest Service, Res. Note SO-301.

Kaelke C.M., Kruger E.L., and Reich P.B., 2001. Trade-offs in seedling survival, growth, and physiology among hardwood species of contrasting successional status along a light-availability gradient. Can. J. For. Res. 31: 1602-1616.

Kelly V.R. and Canham C.D., 1992. Resource heterogeneity in oldfields. J. Veg. Sci. 3: 545-552.

King S.L. and Keeland B.D., 1999. Evaluation of reforestation in the Lower Mississippi River Alluvial Valley. Restor. Ecol. 7: 348-359.

Kormanik P.P., Sung S.S., Kormanik T.L., Schlarbaum S.E., and Zarnoch S.J., 1998. Effect of acorn size on development of northern red oak 1-0 seedlings. Can. J. For. Res. 28: 1805-1813.

Laliberté E., Bouchard A., and Cogliastro A., in press. Optimizing hardwood reforestation in old-fields: the effects of tree shelters and environmental factors on tree growth and physiology. Restor. Ecol.

Legendre P. and Legendre L., 1998. Numerical Ecology, Elsevier Science, Amsterdam, Netherlands.

Lepers E., Lambin E.F., Janetos A.C., Defries R., Achard F., Ramankutty N., and Scholes R.J., 2005. A synthesis of information on rapid landcover change for the period 1981-2000. Bioscience 55: 115-124.

Lima S.L. and Dill L.M., 1990. Behavioral decisions made under the risk of predation: A review and prospectus. Can. J. Zool. 68: 619-640.

Löf M., 2000. Establishment and growth in seedlings of Fagus sylvatica and Quercus robur: influence of interference from herbaceous vegetation. Can. J. For. Res. 30: 855-864.

Löf M., Thomsen A., and Madsen P., 2004. Sowing and transplanting of broadleaves (Fagus sylvatica L., Quercus robur L., Prunus avium L. and Crataegus monogyna Jacq.) for afforestation of farmland. For. Ecol. Manage. 188: 113-123.

Löf M. and Welander N.T., 2004. Influence of herbaceous competitors on early growth in direct seeded Fagus sylvatica L. and Quercus robur L. Ann. For. Sci. 61: 781-788.
Madsen P. and Löf M., 2005. Reforestation in southern Scandinavia using direct seeding of oak (Quercus robur L.). Forestry 78: 55-64.

Manson R.H., Ostfeld R.S., and Canham C.D., 2001. Long-term effects of rodent herbivores on tree invasion dynamics along forest-field edges. Ecology 82: 3320-3329.

McCarthy S.E. and Evans J.P., 2000. Population dynamics of overcup oak (Quercus lyrata) in a seasonally flooded Karst depression. J. Torr. Bot. Soc. 127: 9-18.

Mceuen A.B. and Curran L.M., 2004. Seed dispersal and recruitment limitation across spatial scales in temperate forest fragments. Ecology 85: 507-518.

Meteorological Service of Canada, 2006. Canadian climate normals 1971-2000. Environnement Canada.

Millenium Ecosystem Assessment. 2005. Ecosystems and human wellbeing: Synthesis. Island Press, Washington, DC.

Nilsson U., Gemmel P., Löf M., and Welander T., 1996. Germination and early growth of sown Quercus robur L. in relation to soil preparation, sowing depths and prevention against predation. New For. 12: 69-86.

Ostfeld R.S., Manson R.H., and Canham C.D., 1997. Effects of rodents on survival of tree seeds and seedlings invading old fields. Ecology 78: $1531-1542$.

Puerta-Piñero C., Gómez J.M., and Valladares F., 2007. Irradiance and oak seedling survival and growth in a heterogeneous environment. For. Ecol. Manage. 242: 462-469.

R Development Core Team, 2006. R: A language and environment for statistical computing. R Foundation for Statistical Computing, Vienna, Austria.

Rey Benayas J.M., Espigares T., and Castro-Diez P., 2003. Simulated effects of herb competition on planted Quercus faginea seedlings in Mediterranean abandoned cropland. Appl. Veg. Sci. 6: 213-222.

Rey Benayas J.M., Navarro J., Espigares T., Nicolau J.M., and Zavala M.A., 2005. Effects of artificial shading and weed mowing in reforestation of Mediterranean abandoned cropland with contrasting Quercus species. For. Ecol. Manage. 212: 302-314.

Rice K.J., Gordon D.R., Hardison J.L., and Welker J.M., 1993. Phenotypic variation in seedlings of a "keystone" tree species (Quercus douglasii): the interactive effects of acorn source and competitive environment. Oecologia 96: 537-547.

Sander I.L., 1990. Quercus rubra L. In: Burns R.M., Honkala B.H., (Eds.), Silvics of North America: Hardwoods. Agriculture Handbook 654, USDA Forest Service, Washington, DC.

Sas, 2003. JMP: The Statistical Discovery Software, Cary, NC, USA.

Soil and Plant Analysis Council, 1992. Handbook on reference methods for soil analysis, Council on Soil Testing and Plant Analysis, Georgia University, Athens, GA, USA.

Soucy-Gonthier N., Marceau D., Delage M., Cogliastro A., Domon G., and Bouchard A. 2003. Détection de l'évolution des superficies forestières en Montérégie entre juin 1999 et août 2002 à partir d'images satellitaires Landsat-TM. Institut de recherche en biologie végétale (IRBV), Montréal, QC, Canada.

Tanouchi H., 1996. Survival and growth of two coexisting evergreen oak species after germination under different light conditions. Int. J. Plant Sci. 157: 516-522.

Tomlinson P.T., Buchshacher G.L., and Teclaw R.M., 1997. Sowing methods and mulch affect $1+0$ northern red oak seedling quality. New For. 13: 191-206.

Tonioli M., Escarre J., Lepart J., and Speranza M., 2001. Facilitation and competition affecting the regeneration of Quercus pubescens Willd. Ecoscience 8: 381-391.

Truax B., Lambert F., and Gagnon D., 2000. Herbicide-free plantations of oaks and ashes along a gradient of open to forested mesic environments. For. Ecol. Manage. 137: 155-169.

Wittwer R.F., 1991. Direct seeding of bottomland oaks in Oklahoma. South. J. Appl. For. 15: 17-22. 